American Journal of Pharmacology and Toxicology 1 (4): 87-93, 2006

ISSN 1557-4962

(C) 2006 Science Publications

\title{
Retinoids Chemosensitize Ovarian Cancer Cell Lines to Cisplatin Independent of Nuclear Receptors and p53
}

\author{
${ }^{1,2}$ Suresh Guruswamy and ${ }^{1,2}$ Doris M. Benbrook \\ ${ }^{1}$ Department of Obstetrics and Gynecology and ${ }^{2}$ Department of Biochemistry and Molecular Biology \\ The University of Oklahoma Health Sciences Center, Oklahoma City, OK 73190
}

\begin{abstract}
Treatment of ovarian cancer with cisplatin-based chemotherapy is highly toxic and is often followed by cancer recurrence. Repeated treatments with cisplatin frequently result in the development of resistance to this drug. Drugs with low toxicity that could enhance the tumor cell killing effects of cisplatin could potentially reduce the toxicity and enhance the efficacy of cisplatin. The mechanism of cell kill by cisplatin is partially due to induction of apoptosis through the p53 pathway. Retinoids can regulate apoptosis through nuclear retinoic acid receptors, but the role of p53 in the mechanism varies with the individual retinoid and cell type. The objective of this study was to evaluate the potential of receptor-active and -independent retinoids as chemosensitization of ovarian cancer cell lines with different p53 status. The growth of two ovarian cancer cell lines, OVCAR-3 that has wild type p53 and Caov-3 that has mutant type, was evaluated in the presence and absence of various combinations of cisplatin, a series of retinoids and a chemical inhibitor of $\mathrm{p} 53$ transactivation activity (pifithrin $\alpha$ ). Both receptor active and receptor independent retinoids chemosensitized the two cell lines to cisplatin. PFT $\alpha$ partially attenuated growth inhibition by cisplatin, slightly enhanced the growth inhibition of retinoids and did not affect growth inhibition when retinoids were used in combination with cisplatin. RNase protection demonstrated that PFT $\alpha$ did not alter retinoid effects on p53 regulated genes. In conclusion, retinoids chemosensitize both sensitive and resistant ovarian cancer cells to cisplatin through mechanisms independent of nuclear retinoid receptors and p53.
\end{abstract}

Key words: Retinoids, cisplatin, ovarian cancer, p53, retinoic acid receptors

\section{INTRODUCTION}

The current standard of care for ovarian cancer is surgery followed by intravenous carboplatin and paclitaxel, while intraperitoneal administration of cisplatin and paclitaxel has recently been found to improve survival ${ }^{[1,2]}$. While early stage disease has good prognosis with this therapy, most ovarian cancers are not detected until late stage when platinum based therapies can only provide a prolongation of survival ${ }^{[2]}$. There is also significant toxicity associated with platinum based chemotherapy ${ }^{[3]}$. Thus, low-toxicity compounds that increase the efficacy of platinum drugs could be used to improve their therapeutic effects and/or allow lower doses to be used to decrease the toxicity.

Retinoic acid and synthetic retinoids have the potential to chemosensitize tumors to chemotherapy. These compounds exert their effects through activation of two classes of nuclear retinoid receptors, RARs and RXRs, which act as transcription factors to regulate expression of genes that contain retinoic acid response DNA elements (RAREs). Activation of specific RARs and RXRs has been shown to be responsible for the individual toxicities and teratogenicity associated with retinoids ${ }^{[4-6]}$. The toxicities of retinoids severely limit their clinical use, but some retinoids with RAR/RXRindependent activity, such as fenretinide [N-(4hydroxyphenyl)retinamide] and Flexible Heteroarotinoids (Flex-Hets), do not exhibit the classical retinoid toxicities ${ }^{[7]}$.

Natural retinoic acid isomers and classical retinoids are weak apoptosis inducers, but retinoid related molecules (RRMs) such as 4-HPR, CD437/AHPN, MS3350-1 and Flex-Hets are potent inducers of apoptosis through the intrinsic mitochondrial pathway ${ }^{[7-10]}$. The mechanism of apoptosis is at least partially dependent upon the retinoid receptors for all of these compounds with the exception of Flex-Hets, which are unique in that they induce apoptosis completely independent of RAR and RXR activation ${ }^{[10-12]}$. Several clinical trials of 4-HPR

Corresponding Author: $\quad$ Dr. Doris M. Benbrook, University of Oklahoma Health Sciences Center, 975 NE $10^{\text {th }}$ Street; Room 1372. Oklahoma City, OK 73104, Tel.: 405-271-5523, Fax: 405- 271-3874 
demonstrated limited cancer chemoprevention activity at low doses and tolerable toxicity at higher doses sufficient to induce apoptosis ${ }^{[13-15]}$.

In order to assess the clinical potential of utilizing retinoids to sensitize ovarian cancers to platinum-based chemotherapy, the role of the p53 tumor suppressor in the mechanism of chemosensitization needs to be assessed because it is a major regulator of apoptosis and is mutated in the majority of ovarian cancers ${ }^{16,17]}$. The p53 protein is induced by a variety of cellular stresses and functions as a transcriptional regulator of multiple genes that carry out the signal from p53 to induce cell cycle arrest and DNA repair or to induce apoptosis ${ }^{[18]}$. In addition to the $\mathrm{p} 53$ transcriptional mechanism, p53 can induce apoptosis by direct activation of caspase $8^{[19]}$ and through direct binding to anti-apoptotic Bcl-2 and $\mathrm{Bcl}-\mathrm{X}_{\mathrm{L}}$ proteins on the mitochondria ${ }^{[20]}$. Wild type p53 translocates to the nucleus in correlation with apoptosis, while mutant p53 is present at the mitochondria consitutively ${ }^{[20]}$. Expression of $\mathrm{p} 53$ in ovarian cancer cell lines that are p53 null has been demonstrated to enhance sensitivity to cisplatin, but not to paclitaxel, which has a different mechanism ${ }^{[16]}$. The role of p53 in regulation of apoptosis by receptor active retinoids is dependent upon the cell type $\mathrm{e}^{[21-26]}$. The RRM's induce apoptosis through p53-independent mechanisms, such as 4-HPR regulation of ceramide synthesis and CD437 induction of MAP Kinase ${ }^{[27-29]}$.

The objective of this study was to determine if retinoids regulate growth and cisplatin sensitivity of ovarian cancer cell lines through mechanisms involving nuclear receptors and p53. To evaluate the potential roles of nuclear retinoid receptors, a series of retinoids with different receptor selectivities were compared. To evaluate the potential role of $\mathrm{p} 53$, the response of the OVCAR-3 ovarian cancer cell line that contains wild type p53 was compared to response of the Caov-3 cells line that contains mutant $\mathrm{p} 53$. Also, the effects of a chemical inhibitor (pifithrin $\alpha$, PFT $\alpha$ ) of the wild type p53 transcriptional activity on retinoid and cisplatin growth regulation was studied.

\section{MATERIALS AND METHODS}

Cell lines and drugs: OVCAR- 3 and Caov- 3 ovarian cancer cell lines were obtained from the American Type Culture Collection and were cultured in RPMI supplemented with $10 \%$ fetal bovine serum and antimycotic/antibiotic. The synthetic retinoids (heteroarotinoids - gifts of K. Darrell Berlin, Oklahoma State University) were synthesized as previously described $^{[30-32]}$. The 9-cis-RA (BIOMOL, Plymouth Meeting, PA), heteroarotinoids and PFTa (AG
Scientific, San Diego GA) were dissolved in dimethyl sulfoxide (DMSO) as $1000 \times$ stock solutions, so that the final concentration of DMSO in all cultures was less than $0.1 \%$, which is not cytotoxic and does not induce differentiation. PFT $\alpha$ was added to a final concentration of $10 \mu \mathrm{M}$.

Cytotoxicity assay: Cells were plated at 2000 cells/well in 96 well microtiter plates and allowed to adhere overnight. Cultures were pretreated with $5 \mu \mathrm{M}$ retinoid or the same volume of solvent for 3 days, followed by cisplatin treatment over a range of concentrations from 2 to $200 \mu \mathrm{M}$. The cisplatin was removed after 1 hour and the media was replenished with $5 \mu \mathrm{M}$ retinoid. After 3 days, the percentage of growth inhibition was measured using the CellTiter 96 $\mathrm{AQ}_{\text {ueous }}$ Non-Radioactive Cell Proliferation Assay (Promega Corp., Madison, WI), which is composed of a novel tetrazolium compound that is metabolized by viable cells into a soluble formazan that can be quantitated by reading the OD. Each experiment was performed in triplicate and the three values for each treatment were averaged. To calculate survival, the average OD of the treated cultures was divided by that of the control cultures treated with solvent alone for the cisplatin treatments and retinoid alone for the combination treatments. To calculate percent growth inhibition in Fig. 3 survival was subtracted from the number 1 and the resulting value was multipled by 100 .

RNase protection assay (RPA) analysis: The expression levels of p53 and other DNA damage response genes were compared in cultures treated with various combinations of cisplatin, PFT $\alpha$ and retinoids. RNA was isolated from OVCAR-3 cultures 4 hours after exposure to cisplatin or control solvent and a single multi-probe template set in an RNase protection assay was used to measure expression of DNA damage response genes (p53, bax, c-fos, bcl-2, bcl- $\mathrm{x}_{\mathrm{L}}, \mathrm{p} 21$ and GADD45) and two constitutively expressed genes (L23 and GADPH). RPA was performed using the Riboquant mutli-probe RNase protection assay system kit (Pharmingen,San Diego, California). The hStress-1 probe (Pharmingen,San Diego, California) was radiolabeled by adding $1 \mu \mathrm{L}$ of the template set, $1 \mu \mathrm{L}$ of RNasin, $1 \mu \mathrm{L}$ GACU pool, $2 \mu \mathrm{L}$ DTT, $4 \mu \mathrm{L} 5 \mathrm{X}$ transcription buffer, $1 \mu \mathrm{L}$ of T7 RNA polymerase and $200 \mu \mathrm{Ci}\left[{ }^{32} \mathrm{P}\right]$ UTP $(800 \mathrm{Ci} / \mathrm{mmol}$; Perkin Elmer Life Sciences, Boston, MA) and incubating at $37^{\circ} \mathrm{C}$. After 1 $\mathrm{hr}$, the reaction was terminated by adding $2 \mu \mathrm{L}$ of DNase and radiolabelled probes were extracted with phenol/chloroform and then precipitated with ethanol 

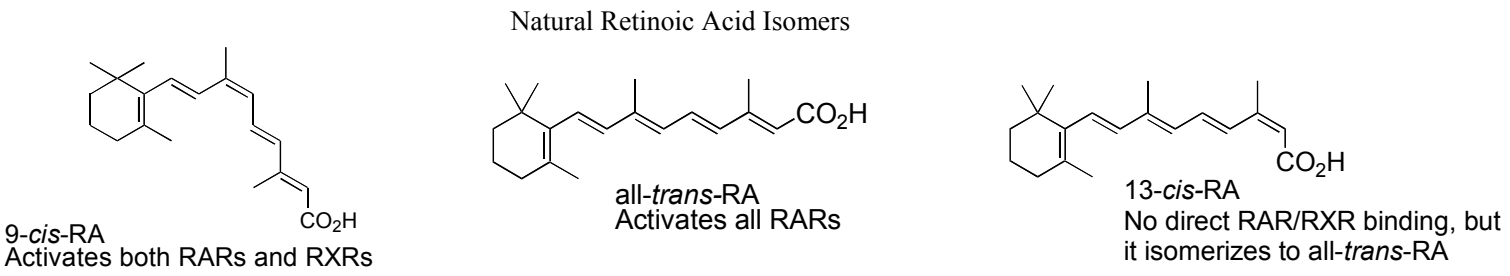

Activates both RARs and RXRs

Synthetic Retinoids and Heteroarotinoids

\begin{tabular}{|c|c|c|c|c|c|}
\hline \multicolumn{3}{|c|}{ Retinoid Receptor Active } & \multicolumn{3}{|c|}{ Retinoid Receptor-Independent } \\
\hline Name & Structure & Specificity & Name & Structure & Specificity \\
\hline OHet72 & & RXRs only & 4-HPR & & $\begin{array}{l}\text { No RAR or RXR } \\
\text { Activation }\end{array}$ \\
\hline SHet50 & & $\begin{array}{l}\text { All RARs } \\
\text { and RXRs }\end{array}$ & SHetA2 & & $\begin{array}{l}\text { No RAR or RXR } \\
\text { Activation }\end{array}$ \\
\hline NHet90 & & $\begin{array}{l}\text { All RARs } \\
\text { and RXRs }\end{array}$ & SHetA3 & & $\begin{array}{l}\text { No RAR or RXR } \\
\text { Activation }\end{array}$ \\
\hline Arot21 & & $\begin{array}{l}\text { Inverse } \\
\text { Agonist of } \\
\text { RARs }\end{array}$ & SHetA4 & & $\begin{array}{l}\text { No RAR or RXR } \\
\text { Activation }\end{array}$ \\
\hline
\end{tabular}

Fig. 1: Structures and receptor specificities of a series of retinoic acid isomers and heteroarotinoids. IUPAC names. SHetA2 [N-4-[(2,3-dihydro2,2,4,4-tetramethyl-2H-1-benzothiopyran-6-yl)-N'-4-nitrophenyl]thiourea] SHetA3[(2,3-dihydro-2,2,4,4-tetramethyl-2H-1benzothiopyran-6-yl)-N'-4-ethoxycarbonylphenyl]thiourea]; SHetA4[N-4-[2,3-dihydro-2,2,4,4-tetramethyl-2H-l-benzothiopyran-6-yl)N'-4-ethoxycarbonylphenyl]urea]; SHet50 [methyl4-[(2,3-dihydro-2,2,4,4-tetramethyl-2H-1-benzothiopyranyl)carbamoyl]benzoate]; NHet17[ethyl4-(4,4-dimethyl- $N$-isopropyl-1,2,3,4-tetrahydroquinolin-6oyloxy)benzoate]; OHet26[methyl 4-(4,4,5,7-tetramethyl-6coumaryl)benzoate]; NHet90[ethyl 4-(N,4,4,7-tetramethyl-1,2,3,4-tetrahydroquinolin-6-oyloxy)benzoate; OHet72 [4-[[4,4-dimethyl-3,4dihydro- $2 H$-benzo[b]pyran-6-yl)-carbonyl] oxy]benzaldehyde thiosemicarbazone]; Arot21[ethyl 4-[(3-methoxy-5,6,7,8tetrahydro5,5,8,8-tetramethylnaphthalen-2-yl)carbonyloxy]benzoate]. 4-HPR $=N$-(4-hydroxyphenyl)retinamide; 9-c-RA $=9$-cis-retinoic acid

and ammonium acetate. The labeled probe was suspended in $50 \mu \mathrm{L}$ of hybridization buffer and diluted to $3 \mathrm{X} 10^{5} \mathrm{CPM} / \mu \mathrm{L}$. The hybridization was carried out by adding $2 \mu \mathrm{L}$ of labeled probe to $10 \mu \mathrm{g}$ of total RNA and incubating overnight at $56^{\circ} \mathrm{C}$. The hybridized probes were digested by adding $100 \mu \mathrm{L}$ of a RNase cocktail containing RNase buffer and RNase A and incubating for $45 \mathrm{~min}$ at $30^{\circ} \mathrm{C}$. The samples were then treated with a Proteinase $\mathrm{K}$ cocktail before extracting with phenol/chloroform and precipitating with ethanol. The hybridization products were separated on a $5 \%$ acrylamide sequencing gel and dried in a vacuum drier. The gel was exposed to phosphormager screens and the intensity of each band was quantified using the
ImageQuant software (Molecular Dynamics, Sunnyvale, California). Only treatments that altered expression levels by 2 fold or more in 2 experiments were considered significant.

\section{RESULTS AND DISCUSSION}

A series of natural and synthetic retinoids with a range of specificities for the retinoid receptors were evaluated for their ability to chemosensitize ovarian cancer cell lines to cisplatin treatment (Fig. 1). The OVCAR-3 line, which was isolated from a cisplatinresistant tumor, was slightly growth stimulated by cisplatin in a dose dependent manner, while the Caov-3 

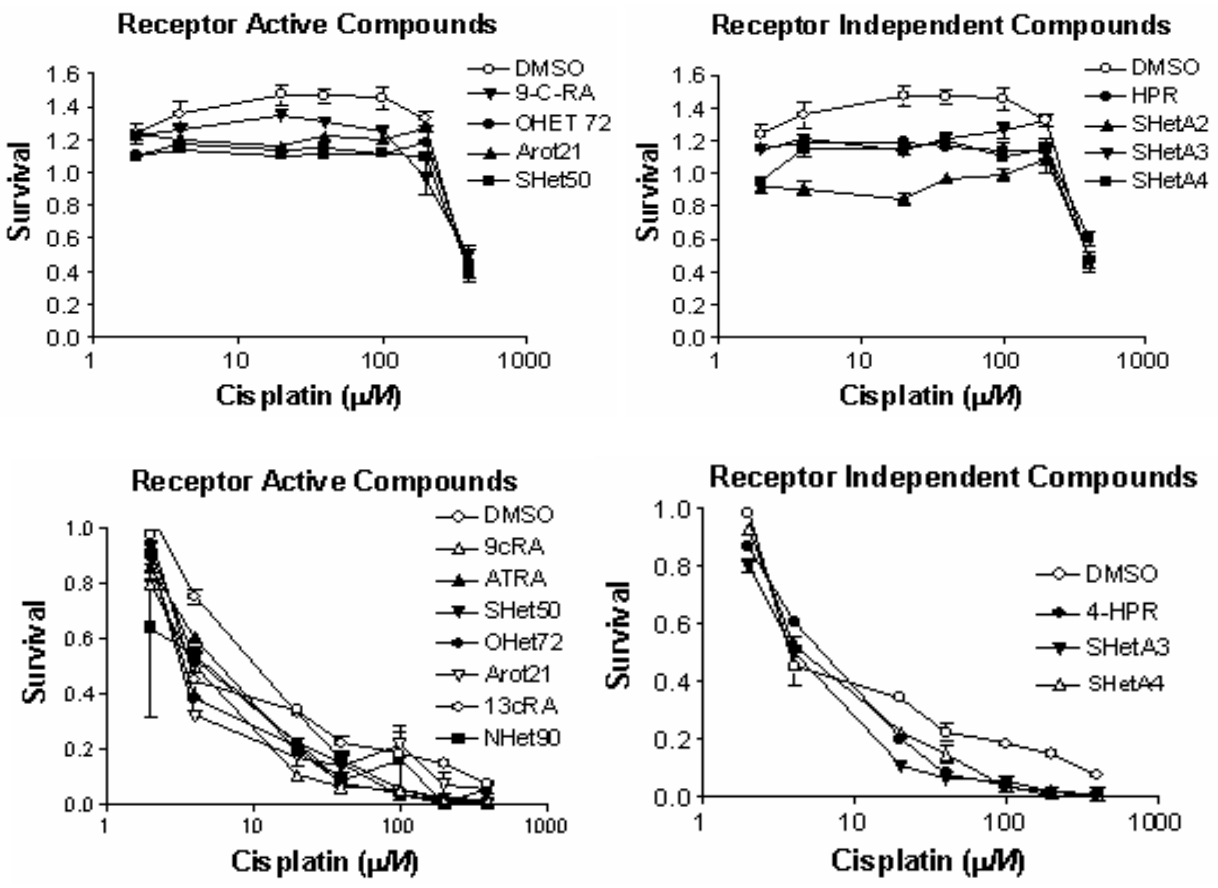

Fig. 2: Chemosensitization of OVCAR-3 (upper panel) and Caov-3 (lower panel). Cultures were treated with individual retinoids or with solvent only for 3 days prior to treatment with a range of cisplatin concentrations for one hour. Retinoid or solvent control treatments were continued for 3 days post-cisplatin exposure and growth was quantified with a cytotoxicity assay. The results presented represent the average and standard error of 3 independent experiments

cell line was growth inhibited (Fig. 2). Pre- and posttreatment with each of the individual retinoid receptor active or the receptor-independent retinoids prevented cisplatin induced growth stimulation in OVCAR-3 and enhanced the cisplatin-induced growth inhibition in Caov-3. The survival of the cultures receiving combined treatments were normalized for the effects of retinoid compound alone, so that the increase in growth inhibition in the combined treatment over that of cisplatin alone exhibited in Fig. 2 is due to an enhanced effect of the combination in excess of the individual retinoid effects.

Roles of $\mathrm{p53}$ in retinoid and cisplatin growth inhibition and chemosensitization: $A$ chemical inhibitor of p53 transcriptional activation, PFT $\alpha$, was used to determine if wild type p53 is involved in the mechanism of cisplatin and retinoid growth inhibition in the OVCAR-3 cell line (Fig. 3). Although PFT $\alpha$ alone did not significantly alter growth, this drug significantly antagonized cisplatin growth inhibition (two tail t test: $\mathrm{p}=0.042$ ). In contrast, PFT- $\alpha$ appeared to enhance the growth inhibition by the retinoids, with the exception of 9-cis-RA, but the effects were not
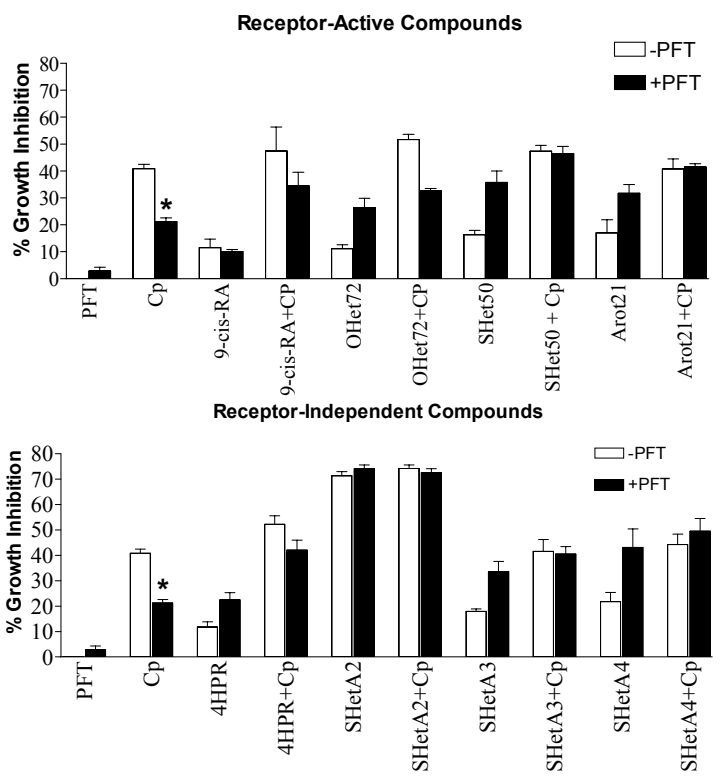

Fig. 3: Role of p53 transcriptional activity in retinoid growth inhibition and chemosensitization. OVCAR-3 cultures were treated with various combinations of $5 \mu \mathrm{M}$ 9-cis-RA, 4HPR, cisplatin (Cp) and PFT $\alpha$ as indicated and the cytotoxicity assay was performed as in Fig. 2. The results are presented as Percent Growth Inhibition $=(1-$ Survival $) 100 . *$ two tail $\mathrm{t}$ test: $\mathrm{p}=0.042$ 

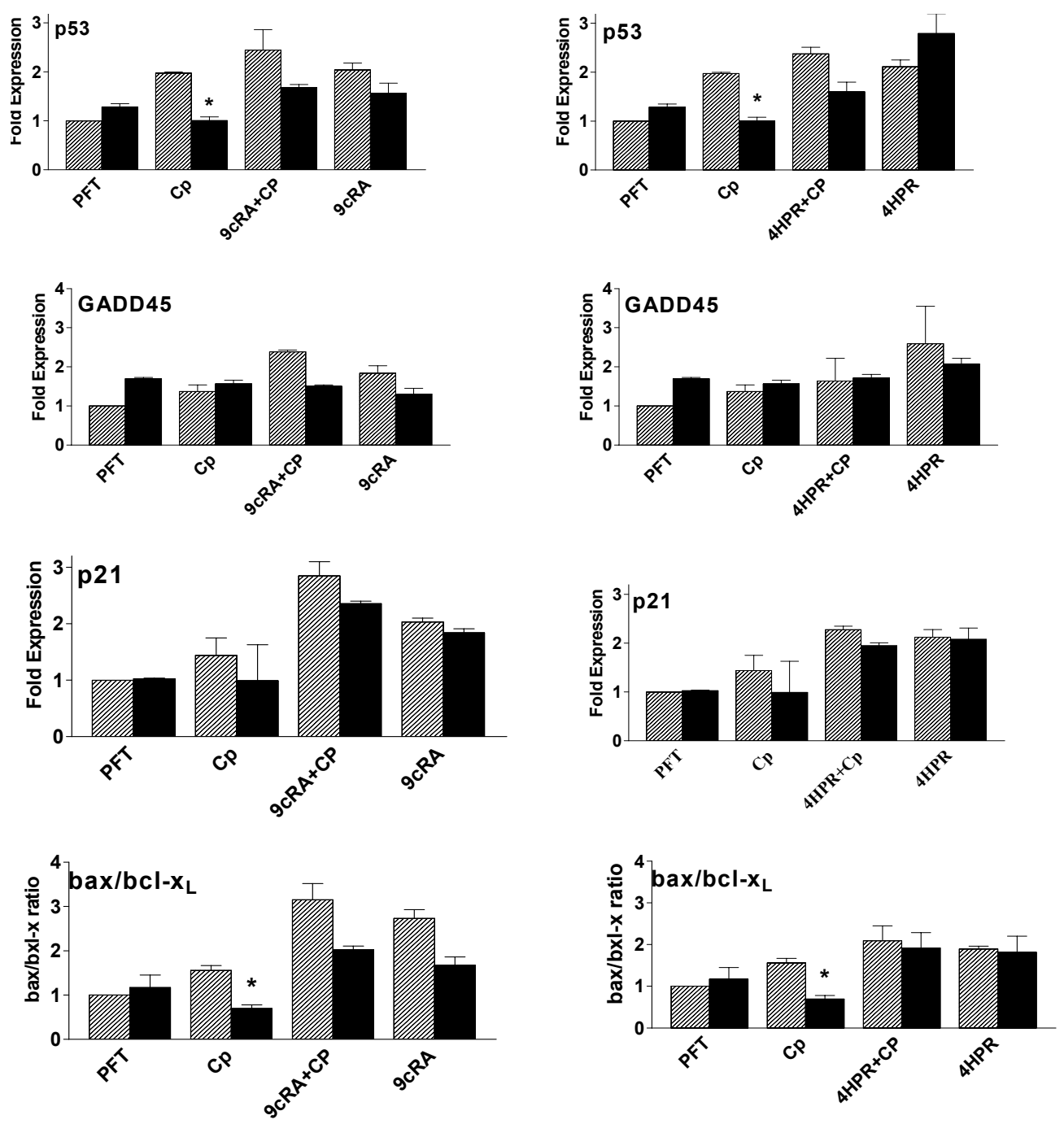

Fig. 4: Role of p53 pathway genes in retinoid chemosensitization. OVCAR-3 cultures were treated with various combinations of $5 \mu \mathrm{M} 9$-cisRA, 4HPR, cisplatin (Cp) and PFT $\alpha$ as indicated. After treatment, the RNA was isolated and evaluated using RPA. The band intensity of the RPA gels were quantified by densitometric tracing. The band intensity for each test gene was normalized by a housekeeping gene. Fold expression was calculated by dividing the normalized intensities of the bands corresponding to each treatment by the normalized band intensity of the untreated solvent control. Only genes exhibiting 2 fold or greater regulation are shown. The bax/bcl- $x_{L}$ ratio was calculated by dividing the band intensity of bax by the band intensity of bcl- $x_{\mathrm{L}}$ for each treatment. * two tailed t-tests $(\mathrm{p}=0.007$ for the effects of $\mathrm{Cp}$ on $\mathrm{p} 53$ and $\mathrm{p}=0.025$ for the effects of $\mathrm{Cp}$ on th $\mathrm{bax} / \mathrm{bcl} \mathrm{x}_{\mathrm{L}}$ ratio)

statistically significant (two-tailed $t$ tests $\mathrm{p}>0.05$ ) (Fig. 3). When cultures were chemosensitized by retinoids, PFTa could no longer antagonize cisplatin growth inhibition.

To explore the role of $\mathrm{p} 53$ and down-stream genes in the mechanism of retinoid chemosensitization, the effects of simultaneous PFT $\alpha$ treatment on the expression of genes in the $\mathrm{p} 53$ pathway (p21, GADD45, bax, bcl-xL, bcl-2 and c-fos) were evaluated using a RNase protection assay. One each of the classical receptor active and apoptosis-inducing retinoids, 9-cis-
RA and 4-HPR, respectively, were chosen for this detailed evaluation. Of all of the genes evaluated, only p53, p21, GADD45 and bax exceeded a 2 fold induction by the drug treatments (Fig. 4). The ratio of the proapoptotic bax to the antiapoptotic bcl- $\mathrm{x}_{\mathrm{L}}$ was increased above 1 (Fig. 4). PFT $\alpha$ significantly antagonized cisplatin induction of $\mathrm{p} 53(\mathrm{p}=0.007)$ and increased $\mathrm{bax} / \mathrm{bcl}-\mathrm{x}_{\mathrm{L}}$ ratio $(\mathrm{P}=0.025)$, but the effects on the other drug/gene combinations were not statistically significant. 
The results of this study demonstrate that retinoids chemosensitize ovarian cancer cell lines to cisplatin. The cisplatin growth inhibition was enhanced in the cisplatin-sensitive Caov-3 cell line, while the slight growth stimulation was prevented in the cisplatinresistant OVCAR-3 cell line. This chemosensitization activity was exhibited by all retinoid compounds tested regardless of their abilities to activate the nuclear retinoid receptors, which suggests that the chemosensitization mechanism is independent of the retinoid receptors. The chemosensitization induced by these compounds the context of both wild type p53 (OVCAR-3) and mutant p53 (Caov-3), supports the hypothesis that the chemosensitization mechanism is independent of $\mathrm{p} 53$. The antagonism of cisplatin growth inhibition by PFT $\alpha$ in the absence, but not the presence of retinoids, provides further support for this hypothesis.

The mechanism of cell kill by cisplatin clearly involves p53 as evidenced by the ability of PFT $\alpha$ to antagonize cisplatin growth inhibition and cisplatin induction of p53 and the pro-apoptotic bax. The other genes that were significantly induced by cisplatin and retinoids, p21 and GADD45, are involved in protection of the cell from apoptosis through their roles in cell cycle arrest and DNA repair ${ }^{[33,34]}$. The lack of PFT $\alpha$ attenuation of the induction of these 2 genes therefore suggests that PFT $\alpha$ is affecting the apoptosis aspect of the p53 pathway and not the cell protective aspect of the p53 pathway.

\section{CONCLUSION}

This study demonstrates the promise of retinoids and RRMs for use as cisplatin chemosensitization agents in cisplatin-sensitive and cisplatin-resistant ovarian cancer. The mechanism of this chemosensitization is not affected by the p53 status of the cellular environment, suggesting that the drugs efficacies will not be limited in the majority of ovarian cancers that have p53 mutations. The similar activities of receptor-active and receptor-independent retinoids indicate that RRMS which lack the classical retinoid toxicities can be used to further reduce patient toxicity.

\section{REFERENCES}

1. Armstrong, D.K., B. Bundy, L. Wenzel, H.Q. Huang, R. Baergen, S. Lele, L.J. Copeland, J.L. Walker and R.A. Burger, 2006. Intraperitoneal cisplatin and paclitaxel in ovarian cancer.[see comment]. N. Eng. J. Med., 354: 34-43.
2. Bhoola, S. and W.J. Hoskins, 2006. Diagnosis and management of epithelial ovarian cancer. Obstet. Gynecol., 107: 1399-410.

3. Hartmann, J.T. and H.-P. Lipp, 2003 Toxicity of platinum compounds. Expert Opin. Pharmacother., 4: 889-901.

4. Collins, M.D. and G.E. Bao, 1999. Teratology of retinoids. Ann. Rev. Pharmacol. Toxicol., 39: 399430.

5. Benbrook, D.M., 2002. Refining retinoids with heteroatoms. Minireviews in Med. Chem., 2: 271277.

6. Silverman, A.K., C.N. Ellis and J.J. Voorhees, 1987. Hypervitaminosis A syndrome: A paradigm of retinoid side effects. J. Am. Acad. Dermatol., 16: 1027-1039.

7. Benbrook, D.M., S.A. Kamelle, S.B. Guruswamy, S.A. Lightfoot, B. Hannafon, T.L. Rutledge, N.S. Gould, S.T. Dunn and K.D. Berlin, 2005. Flexible heteroarotinoids (Flex-Hets) exhibit improved therapeutic ratios as anti-cancer agents over retinoic acid receptor antagonists. Inv. New Drugs, 23: 417-428.

8. Pfahl, M. and F.J. Piedrafita, 2003. Retinoid targets for apoptosis induction. Oncogene, 22: 9058-9062.

9. Guruswamy, S., S. Lightfoot, M. Gold, R. Hassan, K.D. Berlin, R.T. Ivey and D.M. Benbrook, 2001. Effects of retinoids on cancerous phenotype and apoptosis in organotypic culture of ovarian carcinoma. J. Nat. Cancer Inst., 93: 516-525.

10. Chun, K.-H., D.M. Benbrook, K.D. Berlin, W.K. Hong and R. Lotan, 2003. Induction of apoptosis in head and neck squamous cell carcinoma (HNSCC) cell lines by heteroarotinoids through a mitochondrial dependent pathway. Cancer Res., 63: 3826-3832.

11. Sun, S.Y., W. Li, P. Yue, S.M. Lippman, W.K. Hong and R. Lotan, 1999 Mediation of N-(4hydoxyphenyl)retinamide-induced apoptosis in human cancer cells by different mechanisms. Cancer Res., 59: 2493-2498.

12. Holmes, W.F., M.I. Dawson, R.D. Soprano and K.J. Soparano, 2000. Induction of apoptosis in ovarian carcinoma cells by AHPN/CD437 is mediated by retinoic acid receptors. J. Cell. Physiol., 185: 61-67.

13. De Palo, G., L. Mariani, T. Camerini, E. Marubini, F. Formelli, B. Pasini, A. Decensi and U. Veronesi, 2002. Effect of fenretinide on ovarian carcinoma occurrence. Gyn. Oncol., 86: 24-27. 
14. Garaventa, A., R. Luksch, M.S. Lo Piccolo, E. Cavadini, P.G. Montaldo, M.R. Pizzitola, L. Boni, M. Ponzoni, A. Decensi, B. De Bernardi, F.F. Bellani and F. Formelli, 2003. Phase I trial and pharmacokinetics of fenretinide in children with neuroblastoma. Clin. Cancer Res., 9: 2032-2039.

15. Follen, M., E.N. Atkinson, D. Schottenfeld, A. Malpica, L. West, S. Lippman, C. Zou, W.N. Hittelman, R. Lotan and W.K. Hong, 2001 A randomized clinical trial of 4hydroxyphenylretinamide for high-grade squamous intraepithelial lesions of the cervix. Clin. Cancer Res., 7: 3356-3365.

16. Kigawa, J., S. Sato, M. Shimada, M. Takahashi, H. Itamochi, Y. Kanamori and N. Terakawa, 2001. p53 gene status and chemosensitivity in ovarian cancer. Human Cell, 14: 165-71.

17. Feki, A. and I. Irminger-Finger, 2004. Mutational spectrum of p53 mutations in primary breast and ovarian tumors. Crit. Rev. in Oncol.-Hematol., 52: 103-16.

18. Michalak, E., A. Villunger, M. Erlacher and A. Strasser, 2005 Death squads enlisted by the tumour suppressor p53. Biochem. Biophys. Res. Commun., 331: 786-98.

19. Ding, H.-F., Y.-L. Lin, G. McGill, P. Juo, H. Zhu, J. Blenis, J. Yuan and D.E. Fisher, 2000. Essential role for caspase-8 in transcription-independent apoptosis triggered by p53. J. Biol. Chem., 49: 38905-38911.

20. Mihara, M., S. Erster, A. Zaika, O. Petrenko, T. Chittenden, P. Pancoska and U. Moll, 2003. p53 has a direct apoptogenic role at the mitochondria. Mol. Cell, 11: 577-590.

21. Chiu, P.M., H.C. Feng, D.M. Benbrook, H.Y.S. Ngan, U.S. Khoo, W.C. Xue, S.W. Tsao, K.W. Chan and A.N.Y. Cheung, 2006 Effect of all-trans retinoic acid on tissue dynamics of choriocarcinoma cell lines: An organotypic model. J. Clin. Pathol., 59: 845-50.

22. Suzui, M., N. Sunagawa, I. Chiba, H. Moriwaki and N. Yoshimi, 2006. Acyclic retinoid, a novel synthetic retinoid, induces growth inhibition, apoptosis and changes in mRNA expression of cell cycle- and differentiation-related molecules in human colon carcinoma cells. Intl. J. Oncol., 28: 1193-9.

23. Zou, C., J. Zhou, L. Qian, J.M. Feugang, J. Liu, X. Wang, S. Wu, H. Ding, C. Zou, M. Liebert and H.B. Grossman, 2006. Comparing the effect of ATRA, 4-HPR and CD437 in bladder cancer cells. Frontiers in Bioscience, 11: 2007-16.

24. El-Metwally, T.H., M.R. Hussein, S.K. Abd-El-Ghaffar, M.M. Abo-El-Naga, A.B. Ulrich and M.M. Pour, 2006. Retinoic acid can induce markers of endocrine transdifferentiation in pancreatic ductal adenocarcinoma: Preliminary observations from an in vitro cell line model. J. Clin. Pathol., 59: 603-10.
25. Niizuma, H., Y. Nakamura, T. Ozaki, H. Nakanishi, M. Ohira, E. Isogai, H. Kageyama, M. Imaizumi and A. Nakagawara, 2006. Bcl-2 is a key regulator for the retinoic acid-induced apoptotic cell death in neuroblastoma. Oncogene, 25: 5046-55.

26. Mrass, P., M. Rendl, M. Mildner, F. Gruber, B. Lengauer, C. Ballaun, L. Eckhart and E. Tschachler, 2004. Retinoic acid increases the expression of p53 and proapoptotic caspases and sensitizes keratinocytes to apoptosis: A possible explanation for tumor preventive action of retinoids. Cancer Res., 64: 6542-8.

27. Garattini, E., M. Gianni and M. Terao, 2004. Retinoid related molecules an emerging class of apoptotic agents with promising therapeutic potential in oncology: Pharmacological activity and mechanisms of action. Curr. Pharmaceut. Design, 10: 433-48.

28. Corazzari, M., P.E. Lovat, S. Oliverio, F. Di Sano, R.P. Donnorso, C.P.F. Redfern and M. Piacentini, 2005. Fenretinide: A p53-independent way to kill cancer cells. Biochem. Biophys. Res. Commun., 331: 810-5.

29. Holmes, W.F., D.R. Soprano and K.J. Soprano, 2004. Synthetic retinoids as inducers of apoptosis in ovarian carcinoma cell lines. J. Cell. Physiol., 199: 317-29.

30. Benbrook, D.M., M.M. Madler, L.W. Spruce, P.J. Birckbichler, E.C. Nelson, S. Subramanian, G.M. Weerasekare, J.B. Gale, M.K.Jr. Patterson, B. Wang, W. Wang, S. Lu, T.C. Rowland, P. DiSilvestro, C. III Lindamood, D.L. Hill and K.D. Berlin, 1997 Biologically active heteroarotinoids exhibit anticancer activity and decreased toxicity. J. Med. Chem., 40: 35673583 .

31. Zacheis, D., A. Dhar, S. Lu, M.M. Madler, J. Klucik, C.W. Brown, S. Liu, F. Clement, S. Subramanian, G.M. Weerasekare, K.D. Berlin, M. Gold, J.R. Houck, K.R. Fountain and D.M. Benbrook, 1999. Heteroarotinoids inhibit the growth of head and neck cancer cell lines in vitro and in vivo through both RAR and RXR retinoic acid receptors. J. Med. Chem., 42: 4434-4445.

32. Dhar, A., S. Liu, J. Klucik, K.D. Berlin, M.M. Madler, S. Lu, P.J. Birckbichler, R.T. Ivey, D. Zacheis, C.W. Brown, E.C. Nelson and D.M. Benbrook, 1999. Synthesis and structure-activity relationships of nitrogen heteroarotinoids. J. Med. Chem., 42: 3602-3614.

33. Maeda, T., R.A. Espino, E.G. Chomey, L. Luong, A. Bano, D. Meakins and V.A. Tron, 2005. Loss of p21WAF1/Cip1 in Gadd45-deficient keratinocytes restores DNA repair capacity. Carcinogenesis, 26: 180410.

34. Taylor, W.R. and G.R. Stark, 2001. Regulation of the G2/M transition by p53. Oncogene, 20: 1803-15. 